\title{
KAJIAN KEBIJAKAN: KEMITRAAN PUBLIK SWASTA PENANGGULANGAN STUNTING DI INDONESIA DALAM KERANGKA TUJUAN PEMBANGUNAN BERKELANJUTAN
}

\author{
*Brian Sri Prahastuti
}

S2 Kesehatan Masyarakat, Fakultas Kesehatan, Universitas Mohammad Husni Thamrin

Correspondence author: brian.sriprahastuti@gmail.com, Jakarta, Indonesia

DOI: https://doi.org/10.37012/jik.v12i1.124

\begin{abstract}
ABSTRAK
Menurut Riskesdas 2018, satu diantara tiga balita di Indonesia berada dalam kondisi stunted. Stunting terjadi sebagai akibat kekurangan gizi dalam jangka waktu yang lama pada periode 1.000 Hari Pertama Kehidupan. Masalah utama stunting bukan semata-mata karena tinggi badan, tetapi dampaknya pada pertumbuhan dan perkembangan otak. Sejalan dengan komitmen internasional untuk mencapai target Tujuan Pembangunan Berkelanjutan, Badan Perencanaan dan Pembangunan Nasional membuat kerangka kerja multisektor yang menghendaki peranan aktif private sector. Kerangka kerjabersama Public-Private Partnerships adalah sebuah cara modern untuk memfasilitasi sektor swasta untuk memenuhi kebutuhan publik. Kajian ini dilakukan dalam rangka pengembangan model kemitraan dunia usaha di sektor publik untuk penurunan prevalensi stunting. Analisis kebijakan ini merupakan penelitian kualitatif dengan content analysis atas dokumen kebijakan dan hasil diskusi bersama para pakar dan pelaku kebijakan. Penelitian ini dilakukan dalam 4 bulan dengan sumber pendanaan Universitas MH. Thamrin. Penelitian ini menjadi studi awal penelitian lebih lanjut untuk perumusan dokumen formal kebijakan maupun operational research pemodelan PPP untuk penanggulangan stunting. Dengan semakin banyaknya kajian kebijakan, penelitian dan pengabdian masyarakat bertemakan stunting, diharapkan dalam jangka panjang UMHT dapat membuat sebuah Pusat Kajian Pencegahan Stunting (Center for Stunting Reduction Policy Studies).
\end{abstract}

Kata kunci : Kemitraan Publik Swasta, Stunting, Pembangunan Berkelanjutan.

\section{ABSTRACT}

According to Riskesdas 2018, one in three toddlers in Indonesia is in a stunted condition. Stunting occurs as a result of malnutrition in a long period of time in the period of the First 1,000 Days of Life. The main problem of stunting is not solely due to height, but its impact on brain growth and development. In line with international commitments to achieve the Sustainable Development Goals target, the National Planning and Development Agency has developed a multi-sectoral framework that requires an active role in the private sector. A Public-Private Partnerships framework is a modern way to facilitate the private sector to meet public needs. This study was conducted in the context of developing a business partnership model in the public sector to reduce the prevalence of stunting. This policy analysis is a qualitative study with content analysis of policy documents and the results of discussions with experts and policy makers. This research was conducted in 4 months with MH University funding sources. Thamrin. This research is a preliminary study of further research for the formulation of formal policy documents and operational research modeling of PPP for stunting prevention. With the increasing number of policy studies, research and community service with the theme of stunting, it is hoped that in the long run UMHT can establish a Center for Stunting Reduction Policy Studies.

Keywords: Public Private Partnership, Stunting, Sustainable Development. 


\section{PENDAHULUAN}

Satu diantara tiga balita $(30,8 \%)$ di Indonesia dalam kondisi stunted karena pertumbuhan yang tidak optimal (Riskesdas, 2018). Kondisi ini terjadi akibat kekurangan gizi dalam jangka waktu yang lama pada periode 1.000 Hari Pertama Kehidupan. Sekalipun secara fisik, stunting diukur berdasarkan tinggi badan menurut umur dibandingkan terhadap standard WHO (Trihono,2015), tetapi masalah utama stunting adalah dampaknya pada pertumbuhan dan perkembangan otak. dimana 70\% - 80\% terjadi hingga anak usia 24-36 bulan (Bullins J. et al, 2017; Gao W, et al.2009).

Sebagai bagian dari komunitas global, Indonesia mempunyai komitmen internasional untuk mencapai 160 target dari 70 indikator yang diturunkan dari 17 Tujuan Pembangunan Berkelanjutan (TPB). TPB yang berhubungan langsung dengan penurunan stunting yaitu eradikasi kelaparan, mencapai keamanan pangan dan gizi; dan peningkatan pertanian yang berkelanjutan. Pemerintah Indonesia melakukan pendekatan yang holistik untuk mencapai tujuan tersebut. Badan Perencanaan dan Pembangunan Nasional membuat formula integrasi melalui kerangka kerja multisektor. Dalam kerangka kerja ini, Kementerian Kesehatan memegang peranan utama untuk intervensi gizi spesifik, sedangkan kementerian teknis lainnya berperanan untuk intervensi gizi sensitif yang juga sebagai faktor pendukung (Development Initiative, 2018).

Proyeksi penduduk Indonesia pada 2019 berdasarkan Sensus Penduduk 2010 adalah 265 juta, dimana sekitar 24 juta berusia di bawah lima tahun yang tersebar di 514 Kabupaten/Kota di 34 provinsi di Indonesai, dengan latar belakang sosio budaya dan ekonomi yang bervariasi. Jumlah yang sangat besar, mengingat batas toleransi prevalensi stunting menurut WHO hanya 20\%. Diperlukan terobosan dan kolaborasi semua pihak untuk percepatan upaya penurunan stunting. Kolaborasi yang bersifat lintas kementerian, melibatkan pusat-daerah dan kemitraan aktor-aktor pembangunan (Bappenas, 2018).

Pendekatan penurunan stunting dilakukan dengan prinsip kemitraan yang setara, dapat dipertanggungjawabkan, atas dasar kepercayaan dan keyakinan adanya manfaat kepada pihak pihak yang bermitra. Platform pendekatan yang memprioritaskan kemitraan yang mengakomodir aktor-aktor pembangunan yang potensial, yaitu perwakilan pemerintah, swasta dan masyarakat sipil. Di tingkat global, platform ini berupa Scaling Up Nutrition Global Movement yang mengakomodir jejaring kerja lembaga pemerintah, bisnis, 
masyarakat sipil, akademisi/profesi, mitra strategis (badan PBB), dan media (The SUN network, 2017).

Public-Private Partnerships (PPP) adalah cara modern untuk memfasilitasi sektor swasta untuk memenuhi kebutuhan atas infrastruktur publik. Tantangannya sekarang adalah memperluas komponen infrastruktur menjadi pembangunan sosial termasuk pembangunan kesehatan masyarakat. PPP tentunya berbeda dengan Corporate Social Responsibility (CSR) yang telah dikenal luas pengertiannya. Hal ini karena skema PPP memiliki elemen manfaat profit bagi pihak swasta yang terlibat. Kontribusi bisnis bisa dalam bentuk pendampingan dana, produk/barang dan layanan/jasa yang ada di dalam ruang lingkup bisnis masing-masing perusahaan. Sektor swasta yang dimaksud bukan hanya perusahaan (dunia usaha), tetapi juga lembaga filantrofi dan donor penyandang dana yang lebih berorientasi pada manfaat advokasi dan dukungan kebijakan untuk keberlanjutan dan replikasi program yang menghasilkan perubahan yang lebih luas dan lebih berdampak.

Penelitian ini dilakukan dengan tujuan untuk mengkaji kebijakan Pemerintah Indonesia tentang kemitraan dunia usaha, masyarakat sipil dan pemerintah untuk penurunan prevalensi stunting. Lebih khususnya, penelitian bertujuan untuk merumuskan rekomendasi berdasarkan kesenjangan kebijakan yang ada di Indonesia dengan harapan yang seharusnya berlaku sesuai komitmen global, nasional dan pelaksanaan di daerah dan desa yang berhubungan dengan kemitraan dan penaggulangan stunting. Alur kajian dengan merujuk pada model pemecahan masalah menurut Dunn (Nugroho, 2018).

\section{METODE}

Analisis kebijakan ini merupakan penelitian kualitatif yang dilakukan dalam ruang lingkup Negara Kesatuan Republik Indonesia. Sumber utama dari penelitian ini adalah dokumen dan informasi yang didapatkan dari proses desk review dan round table discussion. Dokumen yang dikaji adalah kebijakan tertulis yang ada di Indonesia, komitmen global dan regional yang bersifat mandatory maupun voluntary, dan pengamatan atas pelaksanaan kebijakan di daerah sebagai konsekuensi kebijakan otonomi daerah dan desentralisasi. Desk review dilakukan oleh mahasiswa dengan cara mendaftar dan mengeksplorasi isi dokumen. Round table discussion dilakukan dengan melibatkan narasumber untuk mendapatkan konsensus atas kesenjangan kebijakan dan rekomendasi 
opsi kebijakan. Narasumber ditentukan melalui pemetaan parapihak yang dilakukan oleh peneliti.

Metode analisis dalam penelitian ini adalah content analysis (analisis isi) karena bersifat pembahasan mendalam terhadap isi suatu informasi tertulis atau tercetak. Teknik untuk mengambil kesimpulan dilakukan dengan mengidentifikasi berbagai karakteristik khusus suatu pesan secara obyektif, sistematis dan generalis. Rekomendasi dari penelitian ini adalah opsi kebijakan kemitraan dunia usaha untuk publik yang memprioritaskan proses partisipasi, mengajak kontribusi dan shared values kepada dunia usaha dalam pencapaian prioritas nasional penurunan stunting dengan tetap mempertahankan prinsip bisnis. Advokasi rekomendasi kebijakan dibatasi berupa kertas kerja rencana advokasi kepada Pemerintah Pusat yang memegang peranan koordinasi terkait upaya penurunan stunting dan kaitannya dengan tujuan pembangunan berkelanjutan.

\section{HASIL DAN PEMBAHASAN}

Proses diskusi diawali dengan pencarian kebijakan-kebijakan yang ada baik di tingkat global dan nasional dengan kata kunci stunting, kemitraan dan kerjasama publik swasta. Pencarian menggunakan google search engine menghasilkan 11.900 temuan. Sebagian besar dari hasil pencarian berupa berita (news) dan laporan kegiatan. Dari dokumendokumen di atas dididapatkan beberapa kode yaitu: gagal tumbuh, kurang gizi, sering sakit, tidak mendapat stimulasi, masa 1000 HPK, tinggi badan di bawah normal, perkembangan otak yang terhambat, kerjasama, kerja bersama, multi-stakeholders, pembangunan berkelanjutan, mekanisme pembiayaan tidak tradisional, pembangunan infrastruktur, dan shared values.

Peneliti mensintesa kode-kode tersebut untuk mendefinisikan stunting sebagai: "kondisi gagal tumbuh pada anak karena kekurangan gizi yang disebabkan asupan nutrisi, infeksi berulang dan stimulasi perkembangan yang tidak optimal pada masa 1000 hari pertama kehidupan". Pengertian tersebut hampir sama dengan definisi stunting menurut World Health Organization (WHO) bahwa stunting adalah gangguan pertumbuhan dan perkembangan yang dialami anak-anak akibat kekurangan gizi, infeksi berulang, dan stimulasi psikososial yang tidak memadai. Dua konsekuensi dari stunting bersifat segera maupun jangka panjang, termasuk peningkatan morbiditas dan mortalitas, perkembangan anak yang buruk dan kapasitas belajar, peningkatan risiko infeksi dan penyakit tidak 
menular di masa dewasa, dan berkurangnya produktivitas dan kemampuan ekonomi (Christine et al.2013). Anak-anak dikatakan sebagai stunted jika tinggi badan mereka terhadap usia kurang dari 2 standar deviasi di bawah median Standar Pertumbuhan Anak (WHO, 2006).

Konsisten dengan prioritas intervensi pencegahan stunting pada periode 1000 Hari Pertama Kehidupan, selain status kesehatan dan gizi ibu hamil, maka penting memastikan anak usia di bawah dua tahun mendapatkan ASI hingga minimal dua tahun dan Makanan Pendamping ASI sejak usia 6 bulan. Salah satu komitmen global untuk memastikan hal ini adalah resolusi World Helath Assembly 69.9 bahwa negara-negara anggota, produsen dan distributor makanan bayi dan anak baduta, tenaga profesional penyedia layanana kesehatan, media dan masyarakat sipil untuk menyelaraskan kebijakan, praktik dan program sesuai dengan rekomendasi dalam panduan WHO tentang inappropriate promotion of foods for infants and young children.

Ada banyak faktor yang berpengaruh pada stunting. WHO menggunakan Ethiopia sebagi studi kasus asesmen kerangka kerja stunting reduction dan menemukan adanya hubungan yang konsisten antara pertumbuhan linier yang kurang dengan ukuran bayi baru lahir, kejadian sakit (misalnya diare dan demam), tinggi badan ibu hamil dan tingkat pendidikan (Wirth et al., 2017). Kondisi sanitasi, akses air bersih dan hygiene yang buruk memiliki efek merugikan terhadap pertumbuhan dan perkembangan anak. Sebagai akibat dari paparan pathogen enterik (bakteri E.coli dan cacing) yang terus menerus. Untuk mengurangi stunting, mungkin diperlukan strategi yang baru atau modifikasi yang melampuai lingkup intervensi konvensional dengan tujuan untuk mengatasi paparan pada masa dua tahun kehidupan pertama (Cumming and Cairncross, 2016).

Peneliti mensintesa pengertian public private partnership berdasarkan kode-kode tersebut sebagai: “model kerjasama multi-stakeholder yang melibatkan swasta untuk pembangunan melalui mekanisme pembiayaan yang berbasiskan shared values untuk kepentingan publik". Pengertian tersebut mewakili penggunaan istilah PPP oleh Asian Development Bank bahwa "kemitraan publik-swasta" (KPS) menggambarkan serangkaian kemungkinan hubungan antara entitas publik dan swasta dalam konteks infrastruktur dan layanan lainnya. Dalam PPP terdapat pembagian tugas, kewajiban, dan risiko di atara mitra publik dan swasta. Semakin lama, KPS juga mencakup organisasi non-pemerintah dan organisasi berbasis masyarakat yang mewakili pemangku kepentingan yang terkena 
dampak langsung oleh proyek. Eksplorasi lebih dalam terhadap dokumen-dokumen tersebut ditemukan komitmen-komitmen yang bersifat voluntary maupun mandatory. Paling tidak ditemukan 4 komitmen global yang relevan dengan penurunan stunting, yaitu: Scaling Up Nutrition, Zero Hunger, Global Action Plan on the Prevention of Pneumonia and Diarrhoea, dan Sanitation and Water for All. Komitmen global ini sebagai acuan untuk ditemukan konsistensinya dengan kebijakan nasional yang ada di Indonesia dan implementasinya di sub-nasional dengan memperhatikan akomodasi swasta sebagai ciri dari konsep PPP yang menjadi fokus utama studi ini. Sebagai bagian dari komunitas global, Indonesia mempunyai komitmen untuk mencapai 160 target dari 70 indikator yang diturunkan dari 17 Tujuan Pembangunan Berkelanjutan (TPB) pada tahun 2030 (UN,2015). Setidaknya ada tiga TPB yang berhubungan dengan upaya penurunan stunting di Indonesia, yaitu TPB-2 tentang penghapusan kelaparan, TPB-3 tentang kesehatan dan kesejahteraan, dan TPB-6 tentang sanitasi dan air bersih. TPB-17 relevan dengan inisiatif Public Private Partnership (PPP), karena mengenai kemitraan untuk semua tujuan pembangunan berkelanjutan. Ini artinya, global mengakui bahwa kemitraan multi-pemangku kepentingan adalah kendaraan penting untuk memobilisasi dan berbagi pengetahuan, keahlian, teknologi, dan sumber daya keuangan untuk mendukung pencapaian TPB di semua negara, terutama negara berkembang. Sasaran TPB 17 berupaya lebih jauh untuk mendorong dan mempromosikan kemitraan publik, publikswasta dan masyarakat sipil yang efektif, membangun pengalaman dan sumber daya strategi kemitraan. Berbeda dengan platform pembangunan global (MDGs) 15 tahun sebelumnya, maka TPB dibangun secara partisipatif, bahkan sejak awal mengusulkan prioritas. PBB bekerja sama dengan beberapa lembaga mitranya telah menyelenggarakan survei warga. Hasil survei telah mengumpulkan sebanyak 8, 5 juta lebih suara dari semua negara, 38 ribu suara di antaranya berasal dari Indonesia. Dua prioritas usulan tingkat global maupun Indonesia, yaitu pendidikan yang bermutu dan kesehatan yang lebih baik, berkaitan erat dengan solusi bagi stunting reduction.

Pencapaian Agenda 2030 Tujuan Pembangunan Berkelanjutan akan membutuhkan berbagai sektor dan aktor yang bekerja bersama secara terpadu dengan mengumpulkan sumber daya keuangan, pengetahuan, dan keahlian. Kemitraan untuk pembangunan berkelanjutan merupakan sebuah inisiatif multi-pemangku kepentingan yang dilakukan secara sukarela oleh Pemerintah, Organisasi Masyarakat Sipil (OMS) dan pemangku 
kepentingan lainnya, dimana berupaya untuk berkontribusi dalam pelaksanaan komitmen pembangunan dan pencapaian tujuan sesuai yang disepakati antar negara.

Pembangunan berkelanjutan yang memungkinkan generasi mendatang menerima modal lebih besar dari yang diterima saat ini, telah mengilhami gagasan tentang bisnis yang berkelanjutan, serta lingkungan dan sosial yang berkelanjutan juga. Gagasan tersebut mendorong praktik bisnis tidak semata berorientasi pada tujuan ekonomi perusahaan, tapi juga tujuan secara lebih luas dari sisi lingkungan dan sosial. Pemikiran tentang pembangunan berkelanjutan meyakini bahwa satu sama lain saling terkoneksi dan memperkuat cara pandang masyarakat global terhadap pangan, gizi, air minum, sanitasi dan higiene. TPB-17 yang mengisyaratkan adanya kemitraan publik, publik-swasta dan masyarakat sipil yang efektif untuk mencapai tujuan pembangunan yang berkelanjutan, dimaknai sebagai Public Private Partnership, yaitu cara modern untuk memfasilitasi sektor swasta untuk memenuhi kebutuhan atas infrastruktur publik. Tantangannya sekarang adalah memperluas komponen infrastruktur menjadi pembangunan sosial termasuk pembangunan kesehatan masyarakat.

Public Private Partnership (PPP) berbeda dengan Corporate Social Responsibility (CSR) yang telah dikenal luas pengertiannya. Hal ini karena skema PPP memiliki elemen manfaat profit bagi pihak swasta yang terlibat. Kontribusi bisnis bisa dalam bentuk pendampingan dana, produk/barang dan layanan/jasa yang ada di dalam ruang lingkup bisnis masing-masing perusahaan. Sektor swasta yang dimaksud bukan hanya perusahaan (dunia usaha), tetapi juga lembaga filantrofi dan donor penyandang dana yang lebih berorientasi pada manfaat advokasi dan dukungan kebijakan keberlanjutan dan replikasi program yang menghasilkan perubahan yang lebih luas dan lebih berdampak.

Komitmen pemerintah untuk penanggulanan stunting serta konsisten dengan komitemen global, ditunjukan dengan terbitnya PP No 42 tentang Gerakan Nasional Percepatan Perbaikan Gizi yang dijamin pendanaannya sebagi kegiatan prioritas nasional melalui RPJMN 2014-2019 dan dilanjutkan pada RPJMN 2020-2024 dengan dasar hukum Peraturan Presiden No 2 Tahun 2017 tentang Rencana Jangka Menengah Nasional Tahun 2015-2019 dan Instruksi Presiden No 83 Tahun 2017 tentang kebijakan Strategi Pangan dan Gizi. Operasionalisasinya, telah diatur melalui Peraturan Menteri Kesehatan No 29 tahun 2019 tentang Penanggulangan Masalah Gizi bagi Anak Akibat Penyakit. 
Menerapkan PPP untuk menanganai stunting di Indonesia, mungkin dilaksanakan. Peraturan Presiden No 59 Tahun 2017 tentang pelaksanaan pencapaian Tujuan Pembangunan Berkelanjutan menjadi payung pelibatan sektor swasta, Peraturan Pemerintah No 47 Tahun 2012 tentang Tanggung Jawan Sosial dan Lingkungan Perseroan Terbatas secara umum bisa dijadikan rujukan regulasi, tetapi terbatas pada perusahaan yang bergerak di bidanh Sumber Daya Alam dengan risiko kerusakan lingkungan.

Sebagai tindak lanjut dari kajian ini, diperlukan pemodelan PPP dalam penanggulangan stunting yang mencakup: a) Model kemitraan global multi-pihak yang dapat memfasilitas mobilisasi dan shared pengetahuan, keahlian, teknologi, dan sumber daya finansial. b) Model kemitraan bersama publik, publik-swasta, dan masyarakat sipil yang efektif, yang dibangun bersama berdasarkan pengalaman dan strategi dalam bermitra. c) Mengatur ruang lingkup sektor publik yang bisa dikolaborasikan dalam kerangka PPP. d) Mengatur hak dan kewajiban pemerintah, termasuk tanggung jawab dalam memberikan perlindungan sosial orang miskin sesuai amanat UUD 1945. e) Mengatur kategori dan jenis usaha, hak dan tanggung-jawab, konsekuensi (risiko) serta batasan peran dan fungsi swasta sebagai partner, berikut insentifnya.

Insentif kepada dunia usaha diberikan oleh Pemerintah sebagaimana layaknya dunia usaha menjalankan bisnis, berupa akses terhadap data dan informasi yang akurat mengenai sasaran penerima manfaat, dengan tetap memberikan perlindungan kepada individu dari eksploitasi dan komersialisasi, dukungan sinergi dan koordinasi sumber daya dan pendanaan dengan pemerintah kabupaten dan desa, dengan tetap mempertahankan prinsip pengalokasian dana dan proses pengajuan yang menjadi ciri dari masing-masing, kepastian akan keberlanjutan program serta pengakuan atas kontribusi swasta dan dunia usaha dari pemerintah pusat maupun daerah, potensi pengembangan produk serta menciptakan pasar dan peluang usaha yang berkelanjutan serta berkesinambungan.

\section{SIMPULAN}

Stunting adalah isu global dengan zero hunger, scaling up nutrition, global action for prevention of pneumonia and diarrhea, sanitation and water for all menjadi komitmen 
global. Indonesia sebagai masyarakat internasional telah bersepakat untuk memenuhi komitmen global tersebut serta agenda 2030 Pembangunan Berkelanjutan. Dalam rangka mewujudkan visi manusia unggul Indonesia Maju 2024, Pemerintah Indonesia memprioritaskan pencegahan stunting pada 1.000 Hari Pertama Kehidupan sebagai strategi kunci dalam pembangunan manusia. Kajian ini merekomendasikan formulasi kebijakan dengan pilihan: membuat Peraturan Presiden yang khusus mengatur konsep dan model Public Private Partnership pencegahan stunting, atau merevisi Undang Undang Perseroan Terbatas dan Peraturan Pemerintah tentang Corporate Social Responsibility. Kajian ini juga merekomendasikan dilakukannya advokasi kepada Pemerintah berikut pengajuan ujicoba kerangka kerja di kabupaten terpilih. Pengembangan konsep dilakukan dengan memodifikasi pengalaman penerapan PPP akses air bersih dan sanitasi yang telah terbukti mampu laksana.

\section{UCAPAN TERIMA KASIH}

Terimakasih kepada para tenaga profesional kedeputian 3 Kantor Staf Presiden, Tim Nasional Percepatan Penurunan Kemiskinan (TNP2K), Bappenas serta mitra strategis inovasi PPP stunting reduction (Save the Children, Lazismu, Nashiatul Aisyiah, Kopernik, Indonesia Heritage Foundation, Tanoto Foundation. 1000 days fund foundation, Teman Bumil, Feel Well Ceramic dan Pemerintah Kabupaten Cianjur) atas kontribusi waktu, ide dan buah pikir yang telah memperkaya kajian kebijakan ini.

\section{REFERENSI}

1. Bullins J et al. In: Handbook of Preschool Mental Health: Development, Disorders, and Treatment. Luby JL, editor. The Guilford Press; New York: 2017. pp. 73-97. Retrieved $13^{\text {th }}$ August 2019 from https://zodml.org/sites

2. Balitbangkes. 2018. Riset Kesehatan Dasar. Kemenkes RI. WHO.2019

3. Christine P. et al. Contextualising complementary feeding in a broaderframework for stunting prevention.Maternal and Child Nutrition Journal.2013.

4. Development Initiatives. Global Nutrition Report 2018: Nourishing the SDGs. Bristol, UK.2019 
5. Gao W, et al. Evidence on the emergence of the brain's default network from 2 week old to 2 year old healthy pediatric subjects. Proc Natl Acad Sci U S A. 2009a; 106:6790-5. Retrieved $13^{\text {th }}$ August 2019 from https://www.pnas. org/content/106/16/6790

6. Bappenas. Strategi Nasional Percepatan Pencegahan Stunting.TNP2K. Jakarta. 2018

7. Nugroho, Riant. Public Policy: Analisis Kebijakan Publik. Jakarta. Elex Media Komputindo.2018

8. Oliver Cumming and Sandy Cairncross, "Can water, sanitation and hygiene help eliminate stunting? Current evidence and policy implications," Matern Child Nutr. 12 (Suppl Suppl 1). Wiley Online Library, May 2016) 91-105, https://www.ncbi.nlm.nih.gov/pmc/articles/PMC5084825/.

9. Trihono et al. Pendek (stunting) di Indonesia, Masalah dan Solusi. Lembaga Penerbit Badan Penelitian dan Pengembangan Kesehatan.2015

10. SUN Network. Scaling Up Nutrition (SUN) Movement: Annual Report 2018. Rhome. 2019

11. United Nation. The Sustainable Development Agenda. (2015), https://www.un.org/sustainabledevelopment/developmentagenda/.

12. WHO. The WHO Child Growth Standards. 2006. Retrieved March 31, 2017, from http://www.who.int/childgrowth/standards/en/

13. WHO. Maternal, infant and young child nutrition: The sixty nine world health assembly Geneva, Switzerland. 2016

14. Wirth, J. P., et al.. Assessment of the WHO stunting framework using Ethiopia as a case study. Maternal \& Child Nutrition, 13(2). 2017. Retrieved $4^{\text {th }}$ January 2020 from https://www.ncbi.nlm.nih.gov/pubmed/27126511 